\title{
NEW ZEALAND KARST \\ A VOYAGE ACROSS LIMESTONE LANDSCAPES INTO THE SUBTERRANEAN REALM OF CAVES
}

\author{
MAX WISSHAK, STEFANIE WISSHAK, \\ Speleo-Photo Editions, 2020, \\ 256 pp, 232 colour photos and 3 graphs, $31 \times 22,5 \mathrm{~cm}$, Hardcover
}

ISBN 978-3-9821714-0-1, ISBN 978-3-9821714-1-8(Limited Special Edition)

\author{
Peter GEDEI
}

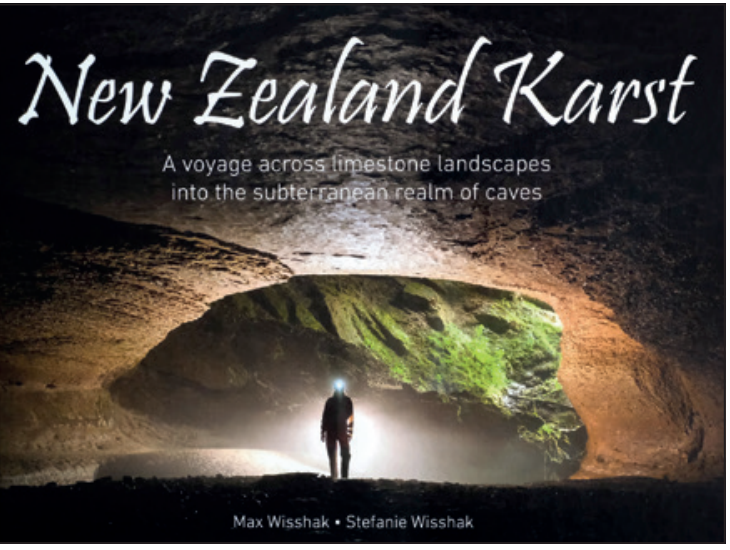

taken with analog technique;

Only few cave photography books have reached a wide international recognition. The best example is the book on Lechugilla Cave, published by Speleo Projects in 1991. The book has been an inspiration to many cave photographers. only in the last trip they used a digital camera. Despite the concern about the quality of the devices at the time, Max managed to squeeze out the top quality pictures from the material. He devotes a short section at the end of the Incredible photos from the "most beautifull cave in the world" were shot by two teams, led by Urs Widmer Kevin Downey and Sure Ballman. The book also inspired Max Wisshak, one of the world's most recognised cave photographers, who dedicated his second book to the late photographer and publisher Urs Widmer.

In his first book, Inside Mother Earth, published in 2009, Max rounded up his photographic journey. The book is graphical, with almost no text, except for the introduction. Two years later, he started to work on a new book on the karst of New Zealand. He presented the idea to Urs Widmer, who was enthusiastic about the project. Max and his wife Stefanie travelled to New Zealand for the third time. Sadly, Urs passed away the following year due to a serious illness. The project was halted, but in 2020 the first edition was published in Max's own publishing house.

Max and Stefanie visited New Zealand three times, last in 2011. Each time they came back with a large amount of photographic material. Most of the shots were

book on how he did this.

The book is divided into 12 chapters, each covering a specific feature of New Zealand's landscape as well as the diversity of the underground. The diversity of climate and landscape of New Zealand is almost extreme. In the first three chapters the book takes us from the mountainous areas of the northern and southern part to the plains, and karst of the rainforest. Besides karst forms at all scales, Max and Stephanie pay a lot of attention to flora and fauna, which stands out in the chapter on the rainforest. Lush vegetation and beautiful colour contrasts are a guarantee for the excellent photographic scenery.

Fourth chapter takes us to the cave entrances, springs, ponors, and deep shafts. Here, the mastery of Max's photography is demonstrated, which culminates in the following chapters on cave chambers, channels and water, the sculptor of the underground world. In a chapter on speleothems, Max demonstrates his utter sense for details. He focuses on classical calcite formations, as well as on the special features such as aragonite and gypsum 
formations. His favourite is certainly the gypsum helictite, which was also the original reason for his visits to New Zealand.

Of course, Max and Stephanie could not avoid cave animals. They dedicate the eighth chapter to them, and the entire ninth chaper to the glow-worms, the wonder of the New Zealand's underground life. They use top-quality macro shots, to clearly present their development and life. Animals are also part of the Chapter 10, which is dedicated to fossile findings of the extinct bird Moe and a whale from the Oligocene period. In a way the penultimate chapter also focuses on the past, especially to transformation of caves to other forms, such as natural bridges.

The last chapter is devoted to the cave painting art of the Māori people. They conclude it with thoughts on the much-needed protection of the karst and its special features, as well as an extensive list of printed and internet materials.

All chapters begin with two pages of in-depth introductory texts. These texts provide better understanding of the photos and their captions. The entire concept of the book is based ona simple form, upgraded with an excellent design, a good selection of typography and, last but not least, artfully placed photographs that round up the whole of each chapter. The final touch to the overall impression is given by superb print with a beautiful reproduction of colours.

Max has been recently focusing to panoramic photography, which is reflected in the book format. The landscape format of photos prevails, but where portrait format could not be avoided, it is there for a reason.

Max's research passion has been recently focused primarily to the Lechuguilla Cave. Given his desire to publish books under his own brand, we can expect a new book in the future, or rather soon, that will most likely describe this american beauty. Judging by the first book, we can hope for another top-notch book from Max's publishing house. The easiest way to the book is through its website https://www.speleo-photo.de. The price is 49.90 EUR and 69.90 EUR in a luxury shield cover.

Peter Gede 